\title{
Asterina Gibbosa: Immune Reactions after Injections of Alkaline Phosphatase
}

\author{
Michel Leclerc \\ 556 rue Isabelle Romée, 45640 Sandillon (France) \\ *Corresponding Author: Michel Leclerc, 556 rue Isabelle Romée, 45640 Sandillon (France)
}

\begin{abstract}
The sea star Asterina gibbosa was injected with the enzyme Alkaline phosphatase twice (1 injection per week). 5 days after the last injection, an immunocytochemical test was performed with the axial organ; it was finally observed in T.E.M. It revealed a positive reaction: an anti-alkaline phosphatase antibody was created.
\end{abstract}

Keywords: sea star; alkaline phosphatase antibody ; immunocytochemical test.

\section{INTRODUCTION}

IN 1973, Leclerc (Ref.1) described, for the first time, a positive immunocytochemical reaction which was obtained with the sea star Asterina gibbosa, after injection of HRP (Horse-radish peroxydase).

Another enzyme used as antigen was then tested: the alkaline phosphatase. In this paper we report this last experiment

\section{Materials AND Methods}

Five Asterina gibbosa (Asterids, Echinodermata) were injected twice with $100 \mu 1$ of a solution $(250 \mu \mathrm{g} / \mathrm{ml})$ each of Alkaline phosphatase (Sigma), on the day 1, then on the day 8. They were sacrified on the day 13. 5 Controls were injected with HRP (Horse-radish peroxydase) (Ref .1). 5 Controls were not injected. All were kept in aquarium in running sea water.

As it was said, on day 13, all were sacrified; axial organs were removed and treated after fixation by immunocytochemical test. But this time incubation was made in an antigenic solution of Alkaline phosphatase at $250 \mu \mathrm{g} / \mathrm{ml}$. The following step was for all axial organs the same: incubation in the solution $(\mathrm{pH}=9)$ according the method of Hugon and Borgers (Ref.2):

Buffer Tris maleate $0,2 \mathrm{M}: 2 \mathrm{ml}$

Beta. Glycerophosphate Na 1, $25 \%: 2 \mathrm{ml}$

Distilled water: $4,7 \mathrm{ml}$

PbNO 3: $\quad$ 1, $3 \mathrm{ml}$
After washing, dehydratation (from alcohol 70 to alcohol $100^{\circ}$ ) Inclusion was performed (Ref.3)

Cut were done. Observations were made in T.E.M with a Hitachi.

\section{RESUlTS}

Specific labelling appears in animals treated with Alkaline phosphatase in the perinuclear space and ergastoplasmic citernae (C E) (Fig. 62-63)

No specific labelling occurs in controls.

We note in controls and in treated animals, a labelling at the level of peroxysomes (P). (Fig. 60-61)

\section{CONCLUSION Discussion}

Specific labelling is shown in alkaline phosphatase treated animals and suggests an ANTIBODY reaction. It recalls the obtained one with Horse-radish peroxydase (HRP) (Ref.1).

No crossed reactions occur in the sea star immune system between HRP and Alkaline phosphatase enzymes.

We know now that this system includes sea star $\mathrm{T}$ and $\mathrm{B}$ lymphocytes (Ref.4) and an Invertebrate Primitive Antibody (IPA) (Ref.5), to be correlated to «anti-alkaline phosphatase antibody.

From day to day, new discoveries appear in this Invertebrate immune system as shown by the sea star humoral response to alkaline phosphatase. 


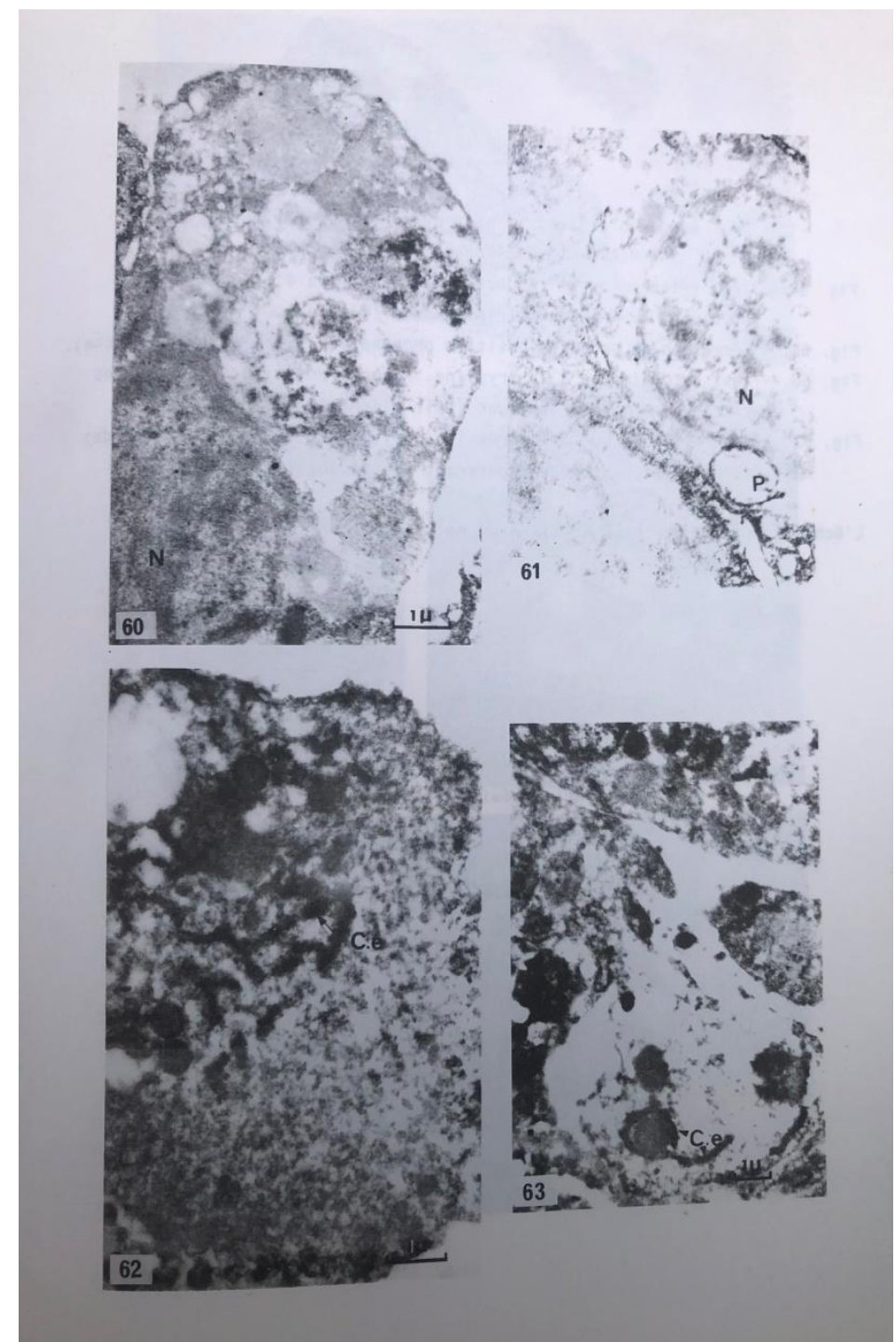

\section{REFERENCES}

[1] Leclerc, M. (1973) Ann. Immun. 124C 363-374

[2] Hugon, J. et al (1966) J.Histochem. Cytochem 14 429-431
[3] Leclerc, M. (1974) Thèse de Doctorat ès Sciences, Orléans (France)

[4] Leclerc, M. et al (1993) Thymus 133-139

[5] Leclerc, M. (2013) Amer. J. Immunol 94-95

Citation: Michel Leclerc, "Asterina Gibbosa: Immune Reactions after Injections of Alkaline Phosphatase”, International Journal of Research Studies in Medical and Health Sciences. 2020; 5(5): 43-44.

Copyright: (c) 2020 Michel Leclerc, This is an open-access article distributed under the terms of the Creative Commons Attribution License, which permits unrestricted use, distribution, and reproduction in any medium, provided the original author and source are credited. 